\title{
Comparison of Fluorometric İmmunoassay and Tandem Mass Spectrometry Methods Used in the Diagnosis of Phenylalanine Metabolism Disorders in Turkish Children
}

\author{
Türk Çocuklarında Fenilalanin Metabolizma Bozukluklarının Tanısında Kullanılan \\ Florometrik İmmünolojik Test ve Tandem Kütle Spektrometresi Yöntemlerinin \\ Karșılaștırılması \\ D Halil Kazanasmaz¹, (D) Meryem Karaca² \\ ${ }^{1}$ Harran University Faculty of Medicine, Department of Pediatrics, Șanlıurfa, Turkey \\ 2Harran University Faculty of Medicine, Department of Pediatric Metabolism Disorders, Şanlıurfa, Turkey
}

\begin{abstract}
Introduction: Phenylketonuria is one of the common causes of preventable mental retardation. Therefore, dietary and/ or cofactor therapy initiated by early detection of the disease is of great clinical importance. In this study, the specificity and sensitivity of fluorescence immunoassay (FIA), tandem mass spectrometry (MS/MS) and plasma amino acid analysis methods used in the diagnosis of phenylalanine metabolism disorder (PMD) were compared.
\end{abstract}

Methods: Patients who were referred to our clinic with a prediagnosis of PMD disorder $(n=163)$ from primary health care institutions were included in the study.

Results: The median age of the patients on admission was 3 months (range: 0-25 months). It was observed that the samples were resent to the newborn screening program at a rate of $68.1 \%$. The sensitivity and specificity of FIA for phenylalanine (Phe) with a cut-off value of $2.95 \mathrm{mg} / \mathrm{dL}$ were $73.3 \%$ and $78.6 \%$, respectively. The sensitivity and specificity of MS/MS for Phe with a cut-off value of $\geq 94.94 \mu \mathrm{mol} / \mathrm{L}$ were $93.3 \%$ and $92.2 \%$, respectively.

Conclusion: A clinical delay was detected in the diagnosis of the cases. Because of this clinical delay, it is considered that the samples in the screening program are repeated frequently and that families do not have enough information about the disease. In our study, it was shown that MS/MS was more effective than FIA. The use of MS/MS instead of FIA for the detection of phenylalanine metabolism disorder in the neonatal screening program may be effective in preventing the diagnostic delay.

Keywords: Phenylketonuria, fluorescence, immunoassay, liquid chromatography, neonatal screening
öZ

Amaç: Fenilketonüri (FKU), önlenebilir zihinsel geriliğin yaygın nedenlerinden biridir. Bu nedenle, hastalığın erken tespiti ile başlatılan diyet ve/veya kofaktör tedavisi, klinik açıdan çok önemlidir. Bu çalışmada, fenilalanin metabolizma bozukluğu (FMB) tanısında kullanılan floresans immünolojik testi (FIA), tandem kütle spektrometrisi (MS/MS) ve plazma amino asit analiz (AAA) yöntemlerinin özgüllüğü ve duyarlılı̆̆ karșılaștırıldı.

Yöntemler: Birinci basamak sağıık kurumlarından FMB $(n=163)$ ön tanısıyla kliniğimize yönlendirilen hastalar çalıșmaya dahil edildi.

Bulgular: Kliniğimize başvuran hastaların medyan yaşı 3 aydı (minimum-maksimum: 0-25). Numunelerin yenidoğan tarama programında $\% 68,1$ oranında tekrar gönderildiği görüldü. FIA ile belirlenen $2,95 \mathrm{mg} / \mathrm{dL}$ fenilalanin (Phe) cut-off değerinde, \%73,3 duyarlılık ve \%78,6 özgüllük saptandı. MS/ MS ile belirlenen Phe $\geq 94,94 \mu \mathrm{mol} / \mathrm{L}$ kesme değeri için \%93,3 duyarlılık ve $\% 92,2$ özgüllük saptandı.

Sonuç: Olguların tanısında klinik bir gecikme tespit edildi. Klinik gecikmeye sebep olarak, tarama programındaki örneklerin sık tekrarlanması ve ailelerin hastalık hakkında yeterli bilgiye sahip olmaması düşünülmektedir. Çalışmamızda MS/MS'nin FIA'dan daha etkili bir yöntem olduğu gösterilmiștir. Yenidoğan tarama programında FMB tespitinde FIA yerine MS/MS kullanımının tanısal gecikmenin önlenmesinde etkili olabileceği düşünülmektedir.

Anahtar Kelimeler: Fenilketonüri, floresans, immünolojik test, sıvı kromatografi, yenidoğan taraması 


\section{Introduction}

Phenylketonuria (PKU) is a hereditary, autosomal recessive (AR) phenylalanine metabolism disorder (PMD) resulting from a variety of mutations in genes encoding phenylalanine hydroxylase (PAH). In the presence of cofactor tetrahydrobiopterin, molecular oxygen and iron PAH normally convert phenylalanine (Phe) to tyrosine (Tyr) (1). The enzyme deficiency causes a significant increase in Phe concentration in the blood and brain, and this can lead to a variety of neurocognitive and neuromotor disorders, including attention deficit symptoms and serious intellectual impairments if left untreated in the neonatal period (2-5). PMD may appear in a wide variety of clinical situations ranging from mild hyperphenylalaninemia (HPA) to classic PKU (5). Considering data from newborn screening programs (NSP), it is observed that the prevalence of $\mathrm{PAH}$ deficiency varies in different regions (for example, it is 1 in 1.000 .000 births in Finland, it is 1 in 4200 births in Turkey) $(5,6)$.

While patients consume normal protein, PMD can be classified according to Phe concentrations (5,7). According to this classification, the groups were defined as classical PKU (Phe $\geq 1200 \mu \mathrm{mol} / \mathrm{L}$, residual PAH activity less than 1\%), mild PKU or HPA (Phe $=600-1200 \mu \mathrm{mol} / \mathrm{L}$, residual PAH activity between 1-5\%), non-PKU-HPA and moderate HPA (Phe=600-120 $\mu \mathrm{mol} / \mathrm{L}$; more than $5 \%$ residual PAH activity) $(2,5,7)$.

In the 1960s, with the development of a simple test by Guthrie and Susi (8) based on a bacterial inhibition assay to detect HPA, PKU became the first disease to be diagnosed and treated early in NSP. Detection of newborns with PKU using this screening test has led to a reduction in the incidence of PKU-associated cognitive deficits when combined with early treatment (9). Over time, the use of fluorometric immunoassay (FIA) and tandem mass spectrometry (MS/MS) methods in screening programs has allowed for more precise and sensitive measurements $(10,11)$. While Guthrie method could only detect positive or negative results, Phe level in heel blood became measurable by FIA method when integrated into NSP (11). Today, Phe levels in heel prick blood are measured more precisely by MS/MS method compared to FIA method and it also provides information about Tyr level simultaneously (12). However, since many different diseases can be detected concurrently with MS/MS method, it is now used as a more cost-effective method in NSP in many developed countries (13-16).

\section{Methods}

This study was conducted in Turkey between 07.05.2018-31.12.2018. Before the study, written informed consent was obtained from the parents of the patients who participated in this study. This study conformed to the principles of the 2008 Declaration of Helsinki and was approved by the Local Ethics Committee of Harran University Faculty of Medicine, Turkey (decision no: Session 5, 19747, date: 03.05.2018).

Out of 216 patients, a total of 163 patients, who were referred to the pediatric metabolic disease clinic after suspicion of PMD by primary health care institutions, were included in the study. Samples for FIA and MS/MS analysis were taken on a filter paper from heel prick blood (FIA: Whatman 903, MS/MS: Whatman 10538018). In all primary health care institutions in Şanlıurfa, samples for NSP were taken on a filter paper in accordance with the manufacturer's instructions. Samples were stored in a refrigerator at $4{ }^{\circ} \mathrm{C}$ for the period from drying at room temperature to laboratory analysis. Samples were moved to central laboratories, which are under the authority of Turkish Public Health Institution, at room temperature conditions twice a week. All Phe levels obtained in NSP were quantitatively determined by FIA (ODAK Neonatal Phenylalanine Assay, ISLAB, İstanbul, Turkey) method in $\mathrm{mg} / \mathrm{dL}$. Sampling on the filter paper for MS/MS analysis was performed simultaneously with plasma amino acid analysis (AAA). Heel prick blood MS/MS analysis results were obtained by liquid chromatography (LC)-MS/MS method (Shimadzu LCMS-8040, Kyoto, Japan). Venous blood samples (2 mL) for plasma AAA were taken into a heparinized tube. The levels of all amino acids detected by plasma AAA were obtained by LC-MS/MS method (Shimadzu LCMS-8045, Kyoto, Japan).

\section{Inclusion and Exclusion Criteria}

According to NSP applied in Turkey, Phe $\leq 2 \mathrm{mg} / \mathrm{dL}$ ( $\leq 120 \mathrm{mmol} / \mathrm{L}$ ) in the heel prick blood sample taken between the $48^{\text {th }}$ hours and seventh day of life is considered negative, patients with Phe values between 2.1 $3.9 \mathrm{mg} / \mathrm{dL}$ are requested to give samples again, and patients with Phe $\geq 4 \mathrm{mg} / \mathrm{dL}$ are directly referred to the pediatric nutrition and metabolic disease clinic $(17,18)$. Also, samples taken during the first 48 hours of life (duplicate) and samples found to be inconvenient in terms of the sampling technique, storage and transportation conditions are taken again (17). In case of repeated heel prick blood sampling, the patient's last sample result was evaluated within the scope of the study. Among the patients who applied to our clinic, those who could not be fed orally for any reason within the first 48 hours of life and who underwent intravenous blood transfusion were excluded from the study. Currently, MS/MS method is recommended in NSPs and Phe $>120 \mu \mathrm{mol} / \mathrm{L}$ value in blood is considered to be significant for moderate HPA (2). Among the patients who were referred from the primary health care institutions, those having Phe $>120 \mu \mathrm{mol} / \mathrm{L}$ with at least one of the plasma AAA or heel prick blood MS/MS methods were evaluated as positive group and followed up. In order to exclude laboratory errors in patients included in the study, a control test was performed at the earliest month in patients who did not receive Phe restricted diet and patients with Phe $>120 \mu \mathrm{mol} / \mathrm{L}$ in plasma AAA were included in the study. Patients with Phe $\leq 120 \mu \mathrm{mol} / \mathrm{L}$ in both heel prick blood MS/MS and plasma AAA were considered as the negative group. In our study, Phe/Tyr ratio was also taken into account (5). In addition, the Phe/Tyr ratio of cases, who was confirmed by only one method (heel prick blood MS/MS or plasma AAA) in the positive group, was more than 3 as assessed by both plasma AAA and heel prick blood MS/MS methods, whereas the Phe/Tyr ratio of all the cases in the negative group was less than 3 as determined by both methods.

\section{Statistical Analysis}

Statistical analysis was performed using SPSS 24.0 version (SPSS Inc., Chicago, IL). Descriptive statistics were expressed as number, percentage, mean, median and standard deviation. The suitability of the variables to the normal distribution was investigated using visual (histogram and probability charts) and analytical methods (Kolmogorov-Smirnov test). Continuous variables were analyzed by either Student's t-test or MannWhitney $U$ test depending on distribution and homogeneity of the 
data. In the correlation analysis, the relationship between sequential variables and numerical variables was performed by Kendall's Tau B test. Specificity and sensitivity analyzes were performed using receiver operator characteristic curve (ROC) analysis method. In the ROC analysis, the area under the curve (AUC) values were studied. Pearson chi-square analysis was used to compare ordinal data. Statistical significance level was accepted as $p<0.05$ in all statistical analyses.

\section{Results}

Among all patients referred to our clinic from primary health care institutions with suspicion of PMD, 163 patients were included in the study. Of the patients, $53.4 \%$ were male and $46.6 \%$ were female. Phe levels of 163 patients were examined with heel prick blood MS/MS and plasma AAA methods, and it was found that eight patients (4.9\%) had classical PKU (Phe $\geq 1200 \mu \mathrm{mol} / \mathrm{L}$ ), one patient (0.6\%) had mild PKU (Phe 600-1200 $\mu \mathrm{mol} / \mathrm{L}$ ), 51 patients (31.3\%) had moderate HPA (Phe 600-120 $\mu \mathrm{mol} / \mathrm{L}$ ), and 103 patients (63.2\%) were PKU negative (Phe $<120 \mu \mathrm{mol} / \mathrm{L}$ ). Sixty patients with PMD (classical-mild PKU and moderate HPA) were evaluated as positive. Accordingly, the percentage of consanguineous marriage among the parents in the positive group was $78.3 \%$ and $36.9 \%$ in the negative group (Table 1). The rate of siblings with PKU was 15\% in the positive group and $2.9 \%$ in the negative group. In the positive group, unexplained sibling death at birth was present in three cases, with one classic PKU and two HPA. There was no unexplained sibling death in the negative group.

The median age at diagnosis was 2 months (range: 0-13 months) in the positive group and it was (range: 0-25 months) in the negative group. The median age at diagnosis in the positive group was statistically significantly lower than the negative group (Table 2). In $68.1 \%$ of the cases, heel prick blood samples taken in NSP were resent due to various reasons (Table 2). In the positive group, NSP replicate samples were sent in $41.7 \%$ of the cases and this rate was significantly higher in the negative group (83.5\%) (Table 2). In the positive group, the number of sample repeats in NSP was statistically significantly lower than the negative group (Table 2). In Kendall's Tau B analysis, there was a positive correlation between the reference age of the patients and the number of repeat heel prick blood screening tests $(r=0.686, p<0.0001)$. Again, there was a negative correlation between the Phe level measured by FIA method and the number of repeat heel prick blood screening test in Kendall's Tau B analysis $(r=-0.368, p<0.0001)$. When 193 samples that were resent for various reasons in NSP were examined, it was found that 112 samples (57.7\%) were resent because they had a Phe value between 2.1-3.9 mg/dL, 51 samples (26.6\%) were taken within the first 24-48 hours of life, and 30 samples (15.7\%) were resent due to inappropriate sampling or transfer (Table 2).

While the mean Phe level of the positive group considered as having PMD was $6.06 \pm 6.26 \mathrm{mg} / \mathrm{dL}$, the mean Phe level measured by FIA was $2.78 \pm 1.13 \mathrm{mg} / \mathrm{dL}$ in the negative group without PMD. The mean Phe level measured by FIA method was significantly higher in the positive group than in the negative group. In the MS/MS analysis, the mean Phe level of the positive group was $394.15 \pm 561.44 \mu \mathrm{mol} / \mathrm{L}$ and the median Phe/Tyr ratio was 2.67. On the other hand, the mean Phe level in the negative group was $64.10 \pm 21.45 \mu \mathrm{mol} / \mathrm{L}$ and the median Phe/ Tyr ratio was 0.84 . The mean Phe level and median Phe/Tyr ratio in the MS/MS analysis were significantly higher in the positive group than in the negative group (Table 2). Finally, the mean Phe level measured by plasma AAA method in the positive group was $396.62 \pm 546.81 \mu \mathrm{mol} / \mathrm{L}$ and the median Phe/Tyr ratio was 2.70. On the other hand, the mean Phe level in the negative group was $61.39 \pm 23.59 \mu \mathrm{mol} / \mathrm{L}$ and the median Phe/Tyr ratio was 0.73. The mean Phe level and median Phe/Tyr ratio measured by plasma AAA method were significantly higher in the positive group than in the negative group (Table 2).

ROC curves were plotted to compare FIA, MS/MS and plasma AAA methods used in the diagnosis of 163 patients with suspected PMD (Figure 1). In the FIA method, AUC was 0.814 ( $p<0.0001)$. Accordingly, sensitivity was $73.3 \%$ and specificity was $78.6 \%$ for a Phe cut-off value of $\geq 2.95 \mathrm{mg} / \mathrm{dL}$ determined by FIA method, while sensitivity was $46.7 \%$ and specificity was $89.3 \%$ for a Phe cut-off value of $\geq 4 \mathrm{mg} / \mathrm{dL}$ (Table 3). In the MS/MS method, AUC was 0.964 ( $p<0.0001)$. Sensitivity and specificity of MS/MS method were $93.3 \%$ and $92.2 \%$, respectively, for a

\begin{tabular}{|c|c|c|c|c|c|}
\hline & \multicolumn{3}{|c|}{ Positive group (Phe $>120 \mu \mathrm{mol} / \mathrm{L}),(\mathrm{n}=60)$} & \multirow{2}{*}{$\begin{array}{l}\text { Negative group } \\
\text { (Phe }<120 \mu \mathrm{mol} / \mathrm{L}),(\mathrm{n}=103)\end{array}$} & \multirow{2}{*}{${ }^{\mathrm{a}} \mathbf{p}$} \\
\hline & Classical PKU, $(n=8)$ & Mild PKU, $(n=1)$ & Moderate HPA $(n=51)$ & & \\
\hline \multicolumn{6}{|l|}{ Gender } \\
\hline Male/Female & $6 / 2$ & $1 /-$ & $24 / 27$ & $56 / 47$ & 0.739 \\
\hline \multicolumn{6}{|l|}{ Age, months } \\
\hline Mean \pm SD (min-max) & $4 \pm 4.87(0-13)$ & 1 & $3.27 \pm 3.66(0-13)$ & $5.40 \pm 4.87(0-18)$ & - \\
\hline $\begin{array}{l}\text { Consanguineous marriage among } \\
\text { the parents, Yes/No }\end{array}$ & 8/- & $0 / 1$ & $39 / 12$ & $38 / 65$ & $<0.001$ \\
\hline PKU history in sibling, Yes/No & $3 / 5$ & $0 / 1$ & $6 / 45$ & $3 / 100$ & 0.009 \\
\hline $\begin{array}{l}\text { Unexplained dead sibling at } \\
\text { birth, Yes/No }\end{array}$ & $2 / 6$ & $0 / 1$ & $1 / 49$ & $0 / 103$ & - \\
\hline $\begin{array}{l}\text { Plasma AAA } \\
\text { Phe level mean } \pm \text { SD }(\mu \mathrm{mol} / \mathrm{L})\end{array}$ & $1741.06 \pm 248.16$ & 713.4 & $179.52 \pm 70.14$ & $61.39 \pm 23.59$ & - \\
\hline Plasma AAA Phe/Tyr ratio & $35.79 \pm 14.86$ & 15.51 & $2.58 \pm 1.31$ & $0.77 \pm 0.32$ & - \\
\hline
\end{tabular}

Phe: phenylalanine, PKU: phenylketonuria, HPA: hyperphenylalaninemia, a: the Pearson chi-square test was carried out between the positive and negative groups as $2 \times 2$, SD: standard deviation, AAA: amino acid analysis, min: minimum, max: maximum 
Phe cut-off value of $\geq 94.94 \mu \mathrm{mol} / \mathrm{L}$ (Table 3). Finally, when the AUC was $0.987(p<0.0001)$, the sensitivity and specificity of plasma AAA method were $95 \%$ and $92.2 \%$, respectively, for a Phe cut-off value of $\geq 101.42$ $\mu \mathrm{mol} / \mathrm{L}$ (Table 3). While 46 of the 60 patients in the positive group were identified as Phe $>120 \mu \mathrm{mol} / \mathrm{L}$ by both heel prick blood MS/MS and

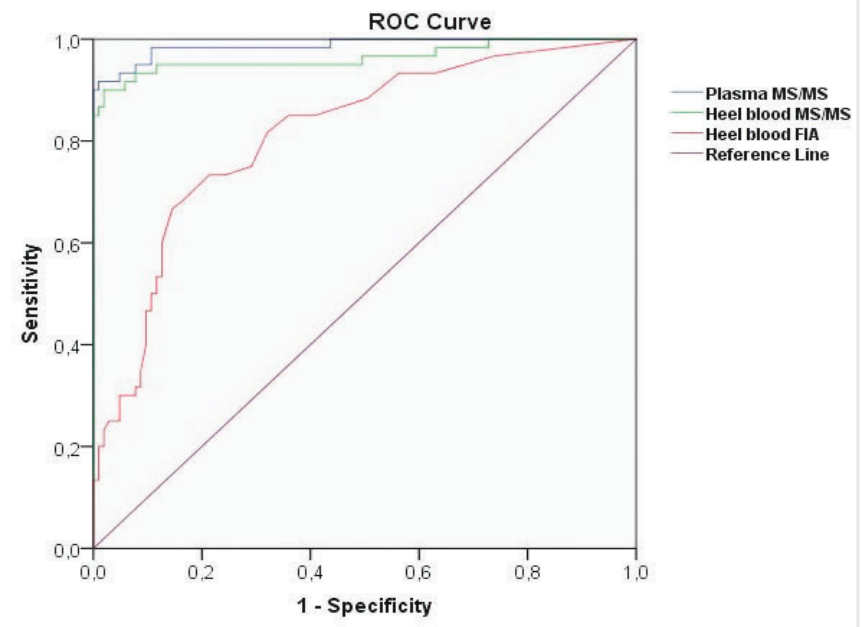

Figure 1. Comparison of $\mathrm{ROC}$ analysis results of phenylalanine level measurement methods

ROC: receiver operator characteristic curve, MS/MS: tandem mass spectrometry, FIA: fluorometric immunoassay plasma AAA method, Phe $>120 \mu \mathrm{mol} / \mathrm{L}$ was determined and considered as positive in eight patients by plasma AAA method. It was seen that 14 patients considered to be positive by a single method had Phe/Tyr ratio $>3$ both in heel prick blood MS/MS analysis and in plasma AAA.

\section{Discussion}

PKU is one of the common causes of preventable motor and mental retardation, and diet and/or cofactor therapy starting with early diagnosis of PKU has great clinical importance (2). Today, NSPs are performed in USA, Canada and most European countries by MS/MS method (14). The traditional FIA method can also be successfully performed in some eastern European countries, such as Slovenia $(15,16)$. NSPs are applied with various methods in many developing Middle Eastern and Latin American countries as MS/MS method is less used (14). However, in some African and Latin American countries, it is still not possible to carry out an effective NSP nowadays (14). NSP for PKU in Turkey is accomplished with FIA method (17). In our study, eight classic PKU cases and one mild PKU case were detected in Şanlıurfa in 2018. Considering the birth rate of Şanlıurfa province in Turkey in 2018, PKU incidence in our study was found to be $1 / 7214$. As PKU is an AR disease, it is more commonly seen in geographical regions with frequent consanguineous marriages, as in Turkey $(2,5,18,19)$. In our study, it was seen that the consanguineous marriages and PKU histories in siblings were more frequent in positive cases with positive PMD compared to the negative group.

Table 2. Repeat sample reasons and comparison of laboratory results of groups

\section{Positive group, (Phe $>120 \mu \mathrm{mol} / \mathrm{L})(\mathrm{n}=60)$}

\section{Age, month}

Median (min-max)

$2(0-13)$

$1(1-4)$

$25 / 35$

\begin{tabular}{|l|}
\hline $35(58.3)$ \\
\hline $14(23.3)$ \\
\hline $7(11.7)$ \\
\hline $4(6.7)$ \\
\hline
\end{tabular}

$21(11)$

$12(6.3)$

- Inappropriate sample

$9(4.7)$

- Phe level is between 2.1 and $3.9 \mathrm{mg} / \mathrm{dL}$

FIA Phe (mean \pm SD) $(\mathrm{mg} / \mathrm{dL})$

$6.06 \pm 6.26$

Heel prick blood MS/MS Phe (mean \pm SD) $(\mu \mathrm{mol} / \mathrm{L})$

Plasma AAA Phe ( $\mu \mathrm{mol} / \mathrm{L})$

Heel prick blood MS/MS Phe/Tyr ratio

Median (min-max)

Plasma AAA Phe/Tyr ratio

Median (min-max)

$394.15 \pm 561.44$

$396.62 \pm 546.81$

$2.67(0.27-52.68)$

$2.70(0.81-64.79)$

\section{Negative group, $(\mathrm{Phe}<120 \mu \mathrm{mol} / \mathrm{L})(\mathrm{n}=103) \quad \mathrm{p}$}

$4(0-25)$

${ }^{\mathrm{a}} 0.001$

\begin{tabular}{l|l}
\hline $2(1-4)$ & $\mathrm{a}<0.0001$ \\
\hline $86 / 17$ & ${ }^{\mathrm{b}}<0.0001$
\end{tabular}

$17(16.5)$

36 (35)

33 (32)

17 (16.5)

30 (15.6)

$18(9.4)$

102 (53)

$2.78 \pm 1.13$

${ }^{c}<0.0001$

$64.10 \pm 21.45$

$61.39 \pm 23.59$

$c<0.0001$

$0.84(0.14-2.37)$

${ }^{c}<0.0001$

${ }^{\mathrm{a}}<0.0001$

$0.73(0.14-1.92)$

${ }^{\mathrm{a}}<0.0001$

a: analyzed by Mann-Whitney U test, ${ }^{\text {b: }}$ pearson chi-square, c: student's t-test, duplicated sample: sample taken within the first 24-48 hours of life, FIA: fluorometric immunoassay, MS: mass spectrometry, Phe: phenylalanine, Plasma AAA: amino acid analysis measurement from venous blood by mass spectrometry method, SD: standard deviation, Tyr: tyrosine, min: minimum, max: maximum 
Table 3. Comparison of test methods used for phenylalanine metabolism disorders

\begin{tabular}{|l|l|l|l|l|l|}
\hline & AUC & Cut-off value & Sensitivity (\%) & Specificity (\%) & p \\
\hline $\begin{array}{l}\text { Heel prick blood FIA Phe } \\
\text { (mg/dL) }\end{array}$ & 0.814 & 2.95 & 73.3 & 78.6 & $<9.3$ \\
\hline Heel prick blood MS/MS Phe, $(\boldsymbol{\mu m o l} / \mathbf{L})$ & 4 & 46.7 & 93.2 & $<0.0001$ \\
\hline Plasma AAA Phe, $(\boldsymbol{\mu m o l} / \mathbf{L})$ & 0.964 & 94.94 & 93.3 & 92.2 & $<0.0001$ \\
\hline
\end{tabular}

AAA: amino acid analysis, AUC: area under the ROC Curve, MS/MS: tandem mass spectrometry, Phe: phenylalanine, Tyr: tyrosine

Because delays in PKU can lead to serious mental problems, early diagnosis of the disease is extremely important $(2,20)$. As a matter of fact, when the reasons for delay in NSPs are examined in the past, the most common reason is stated as "not having an effective NSP" (21). In our study, the median age at diagnosis was 2 months in the positive group and 4 months in the negative group. The cases in the positive group were admitted to our clinic at a significantly earlier age than the negative group, but delayed admission was determined in both groups. When the possible causes of clinical delay were examined, considering the flowchart of NSP applied for PMD in Turkey, it was seen that the sample could be obtained from the infant after the fourth time due to repeated and/or inappropriate sampling and/ or because Phe levels were detected between 2.1-3.9 mg/dL. In our study, only $31.9 \%$ of the cases were referred to our clinic after the first sampling in NSP. Kendall Tau-B correlation analysis showed a positive correlation between age at admission to our clinic and the number of NSP sample repeats. Repeat sample rate was $83.5 \%$ in the negative group with lower mean Phe values and $41.7 \%$ in the positive group with higher mean Phe values. In the negative group, repeat sample rate was found to be significantly higher than the positive group. As a matter of fact, in Kendall Tau-B correlation analysis, there was a negative correlation between FIA Phe level and number of NSP repeat sample. In our study, it was emphasized that every repeat sample may contribute to delayed diagnosis since the parents should be reached again.

Since clinically late diagnosis of PKU cases can cause serious mental problems, it is thought that it would be useful to investigate the presence and causes of diagnostic delay together with the studies to be performed in different clinical centers. In a study carried out by Heidari et al. (22) in Iran, attention has been drawn to the difficulty faced by physicians to reach the families and to raise awareness in NSP for PKU, inability to implement the screening program entirely in the country as well as the social and financial problems of the families. Despite the effective implementation of NSP in Turkey, problems in reaching families on time and raising awareness are considered to be likely. As a matter of fact, the mean age of the patients with classic PKU who were referred to our clinic after the first screening test was $4 \pm 4.87$ (range: $0-13$ ) months. While five patients were treated within the first two months, it was seen that the families had low educational and socio-economic status and did not have enough awareness about the importance of the disease in three cases with diagnostic delay. Therefore, it is thought that there may be a delay in the diagnosis due to the socio-economic and educational level of the parents even if the sampling is not repeated.
In our study, it was determined that a total of 193 repeat samples were sent by primary health care institutions in NSP. When the reasons of repeat samples were examined, the most frequent reason was Phe levels being in the range of $2.1-3.9 \mathrm{mg} / \mathrm{dL}$ and duplicate sampling. It is thought that both causes may be directly related to the specificity and sensitivity of the FIA method used in the screening. In fact, blood Phe levels were also measured by simultaneous plasma AAA and heel prick blood MS/MS methods in all cases directed to our clinic. As a result of the ROC analysis performed for the FIA method, although the FIA method used in NSP had a certain specificity and sensitivity, it was found to be inadequate ( $A \cup C=0.814$ ). The MS/ MS method was found to be more specific and sensitive than the FIA method ( $A \cup C=0.964$ ) (Figure 1). Today, heel prick blood MS/MS method is used together with plasma AAA in the clinical follow-up of patients with PKU (2). Although the most specific and sensitive test was plasma AAA as expected in our study, heel prick blood MS/ MS method was also found to be able to perform highly effective analysis (Table 2).

\section{Conclusion}

Despite the fact that the first screening tests of the cases were performed with FIA method at the appropriate time in NSP in Turkey, patients with suspected PMD as a result of screening were found to referred late to the pediatric metabolic disease clinic. Moreover, it was thought that socioeconomic and educational status of the families could contribute to the clinical delay in cases where repeat samples were not sent. Depending on the socio-economic status and educational level, the presence of family-related diagnostic delay may be considered as a limitation of our study. Further studies in various centers are needed. In our study, MS/MS has been shown to be a more effective method than FIA. It is thought that the use of MS/MS instead of FIA in the NSP for the PMD may be effective in avoiding the diagnostic delay.

Ethics Committee Approval: This study conformed to the principles of the 2008 Declaration of Helsinki and was approved by the Local Ethics Committee of Harran University Faculty of Medicine, Turkey (decision no: Session 5, 19747, date: 03.05.2018).

Informed Consent: Before the study, written informed consent was obtained from the parents of the patients who participated in this study.

Peer-review: Externally peer-reviewed.

Author Contributions: Concept - H.K.; Design - H.K., M.K.; Data Collection and/ or Processing - H.K., M.K.; Analysis and/or Interpretation - H.K., M.K.; Literature Search - H.K., M.K.; Writing Manuscript - H.K. 
Conflict of Interest: No conflict of interest was declared by the authors.

Financial Disclosure: The authors declared that this study received no financial support.

\section{References}

1. Blau N, van Spronsen FJ, Levy HL. Phenylketonuria. Lancet 2010; 376: 141727.

2. van Wegberg AMJ, MacDonald A, Ahring K, Belanger-Quintana, Blau N, Bosch AM, et al. The complete European guidelines on phenylketonuria: diagnosis and treatment. Orphanet J Rare Dis 2017; 12: 162.

3. Al Hafid N, Christodoulou J. Phenylketonuria: a review of current and future treatments. Transl Pediatr 2015; 4: 304-17.

4. Berry SA, Brown C, Grant M, Greene CL, Jurecki E, Koch J, et al. Newborn screening 50 years later: Access issues faced by adults with PKU. Genet Med 2013; 15: 591-9.

5. Burgard P, Lachmann RH, Walter J. Hyperphenylalaninaemia. In: Saudubray, JM, van den Berghe, G, Walter JH. Inborn metabolic diseases: Diagnosis and Treatment 6th ed. New York: Springer, 2016;253-4.

6. YıldızY, Dursun A, Tokatlı A, Coşkun T, Sivri HS. Late-diagnosed phenylketonuria in an eight-year-old boy with dyslexia and attention-deficit hyperactivity disorder. Turk J Pediatr 2016; 58: 94-6.

7. Thiele AG, Gausche R, Lindenberg C, Beger C, Arelin M, Rohde C, et al. Growth and final height among children with phenylketonuria. Pediatrics 2017; 140. pii: e20170015

8. Guthrie R, Susi A. A simple phenylalanine method for detecting phenylketonuria in large populations of newborn infants. Pediatrics 1963; 32: $338-43$.

9. Dobson JC, Williamson ML, Azen C, Koch R. Intellectual assessment of 111 four-year-old children with phenylketonuria, Pediatrics 1977; 60: 822-7.

10. Chace DH, Millington DS, Terada N, Kahler SG, Roe CR, Hofman LF. Rapid diagnosis of phenylketonuria by quantitative analysis for phenylalanine and tyrosine in neonatal blood spots by tandem mass spectrometry. Clin Chem 1993; 39: 66-71.

11. Gerasimova NS, Steklova IV, Tuuminen T. Fluorometric method for phenylalanine microplate assay adapted for phenylketonuria screening. Clin Chem 1989; 35: 2112-5
12. Wagner M, Tonoli D, Varesio E, Hopfgartner G. The use of mass spectrometry to analyze dried blood spots. Mass Spectrom Rev 2016; 35: 361-438.

13. Vockley J, Andersson HC, Antshel KM, Braverman NE, Burton BK, Frazier DM, et al. Phenylalanine hydroxylase deficiency: diagnosis and management guideline. Genet Med 2014; 16: 188-200.

14. Therrell BL, Padilla CD, Loeber JG, Kneisser I, Saadallah A, Borrajo GJ, et al. Current status of newborn screening worldwide: 2015. Semin Perinatol 2015 39: 171-87.

15. Šmon A, Grošelj U, Žeçrjav Tanšek M, Biček A2, Oblak A2, Zupančič M, et al. Newborn screening in Slovenia. Zdr Varst 2015; 54: 86-90.

16. Smon A, Repic Lampret B, Groselj U, Zerjav Tansek M, Kovac J, Perko D, et al. Next generation sequencing as a follow-up test in an expanded newborn screening programme. Clin Biochem 2018; 52: 48-55.

17. Republic of Turkey Ministry of Health, Public Health Agency of Turkey, Child and Adolescent Health Department. Accessed on: 12 November 2018 https:// dosyaism.saglik.gov.tr/Eklenti/11173,259822214447pdf.pdf?0

18. Tezel B, Dilli D, Bolat H, Sahman H, Ozbaș S, Acıcan D, et al. The developmen and organization of newborn screening programs in Turkey. J Clin Lab Anal 2014; 28: 63-9.

19. El-Metwally A, Yousef Al-Ahaidib L, Ayman Sunqurah A, Al-Surimi K, Househ M, Alshehri A, et al. The Prevalence of phenylketonuria in Arab Countries, Turkey, and Iran: A systematic review. BioMed Research International 2018:7697210.

20. Mazlum B, Anlar B, Kalkanoğlu-Sivri HS, Karlı-Oğuz K, Özusta \$, Ünal F, et al. A late-diagnosed phenylketonuria case presenting with autism spectrum disorder in early childhood. Turk J Pediatr 2016; 58: 318-22.

21. Vela-Amieva M, Ibarra-González I, Fernández-Lainez C, Monroy-Santoyo S, Guillén-López S, Belmont-Martínez L, et al. Causes of delay in referral of patients with phenylketonuria to a specialized reference centre in Mexico. J Med Screen 2011; 18: 115-20.

22. Heidari A, Arab M, Etemad K, Damari B, Kabir MJ. Challenges of implementation of the national phenylketonuria screening program in Iran: A qualitative study. Electron Physician 2016; 8: 3048-56. 